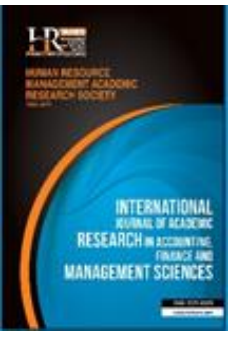

International Journal of Academic Research in Accounting, Finance and Management Sciences

Vol. 8, No.2, April 2018, pp. 126-131

E-ISSN: 2225-8329, P-ISSN: 2308-0337

(c) 2018 HRMARS

www.hrmars.com

To cite this article: Anghelache, C., Popescu, A.M., Anghel, M.-G. (2018). Portfolio of Loans, Guarantees and Provisions, International Journal of Academic Research in Accounting, Finance and Management Sciences 8 (2): 126-131.

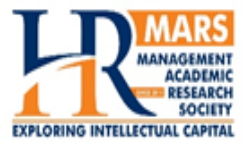

http://dx.doi.org/10.6007/IJARAFMS/v8-i2/4189 (DOI: 10.6007/IJARAFMS/v8-i2/4189)

\title{
Portfolio of Loans, Guarantees and Provisions
}

\author{
Constantin ANGHELACHE ${ }^{1}$, Ana Maria POPESCU ${ }^{2}$, Mădălina-Gabriela ANGHEL ${ }^{3}$ \\ ${ }^{1}$ Bucharest University of Economic Studies/„,Artifex” University of Bucharest, Romania, ${ }^{1}$ E-mail: actincon@yahoo.com \\ ${ }^{2}$ Bucharest University of Economic Studies, Romania, ${ }^{2} E$-mail: notariat.dejure@gmail.com \\ ${ }_{3}^{3}$,Artifex" University of Bucharest, Romania, ${ }^{3}$ E-mail: madalinagabriela anghel@yahoo.com
}

\begin{abstract}
Economic development is realized on the resources of the society. In addition to work and capital accumulation, financial resources play an important role in economic evolution and growth. Economic agents that do not currently have the necessary financial resources use the bank loans. From this perspective, the banking system is important in ensuring the financing of economic activities. The involvement of banks in lending involves the prospect of risk-taking, which is often imminent. We can talk about a loan portfolio, which the bank has to handle in a prudential way. An important element in hedging is the provisioning. They are formed at the beginning of the following year from the income achieved in the balance sheet of the previous year and must be weighted at the level of the pre-calculated risks. The authors also refer to the fact that bank risks can exceed, as a result, the level of provisions set up to cover the losses. It also underlines the need for the guarantees to be granted, especially long-term loans, to be sound, real and secured to cover the effect of the disappearance or diminution of the value of these guarantees. In this study, the authors focus on analyzing the correlation between the loan portfolio and the provisioning. Relevant data will be presented to highlight the level of contracted loans and, on this basis, the provisions made. Statistical and econometric methods and models will be used (data series, tables, graphs etc.) which quantify the correlation between the loan portfolio and the provisioning requirements to cover the credit risks.
\end{abstract}

Key words

Loan Portfolio, Provision, Bank Risk, Econometric Model, Financial Resources

Received: 10 May 2018 (c) The Authors 2018

Revised: 30 May 2018 Published by Human Resource Management Academic Research Society (www.hrmars.com

Accepted: 04 Jun 2018 This article is published under the Creative Commons Attribution (CC BY 4.0) license. Anyone may reproduce, distribute, translate and create derivative works of this article (for both commercial and noncommercial purposes), subject to full attribution to the original publication and authors. The full terms of this license may be seen at: http://creativecommons.org/licences/by/4.0/legalcode

\section{Introduction}

In the national economy, using the credit system for the needs of the economy is, of course, very important. Every bank has some limits to which it can provide loans, they are pursued by the rules of the national bank, in our case the NBR, and they are used by the economic agents in order to reintegrate their sources of financing so that they carry out activities that be effective and produce results. At commercial banks, credit quality is the risk, in the sense that risks are not sufficiently well correlated. They lead to bad loans, to large enough losses that the banks record. In banking management, the issue is to permanently analyze the correlation between the loan portfolio and hedge funds. In the article, the authors referred extensively to the provisions made by the commercial banks in the net results, so that the eventual occurrence and manifestation of the credit risks did not affect the activity and the results recorded in the national economy by the Romanian banking system. We can recall that in the last decade of the last century, a large number of commercial banks in Romania went into insolvency and then went bankrupt because these effects of credit risk as well as other banking risks in the entire risk system were not correct 
correlated, highlighted and used. This article expresses in concrete terms the situation in which certain circumstances have arisen as a result of the lack of correlation of the loan portfolio may be affected by banking risks and the constitution of those provisions. It should also be borne in mind that the authors make these references, stating that, in the case of loans, they must be constituted by the economic agents who make use of them, solid guarantees that can be executed in the event of non-performance and thereby ensure the completion or full recovery of credits that have been granted.

Also, with reference to the classification of credits for the provisioning of provisions, some clarifications have been made regarding the provisions of Regulation no. 1/2018 of the National Bank of Romania, applying IFRS no. 9.

\section{Literature review}

Aebi et al. (2012) investigated aspects of risk management and performance of credit institutions in the context of the financial crisis. Agarwal et al. (2018) analyzed and proposed a new approach to investigating the transfer of credit expansion policies, focusing on frictions such as asymmetric information that arise in the interaction between banks and borrowers. Agoraki et al. (2011) studied the correlation between regulations, competition and bank risk assumption in transition countries. Anghel et al. (2016) presented a model of credit risk analysis. Anghel (2015) investigated the main bank risks and methods of managing them. Anghelache et al. (2017a) addressed elements of the importance of information in modeling decisions and risks. Anghelache et al. (2017b) studied the causes and effects of the insolvency phenomenon in banking institutions. Anghelache et al. (2016) analyzed and presented the main elements regarding bank risks. Anghelache and Anghel (2014) studied credit types, credit risks and the main methods and models for their management. Anghelache (2010) analyzed the main risk-measurement methods and models in the financial-banking field. Anghelache et al. (2009) investigated a series of issues related to the prevention of banking risks. Awdeh et al. (2011) investigated the impact of capital requirements on bank risk. Chen and Wu (2014) conducted a study on credit growth in emerging markets during and after the 2008-2009 financial crisis. Bushman and Williams (2012) addressed provisioning issues that reflect the timely recognition of expected future loan losses and which is associated with increased risk-taking discipline. Claeysa and Vander Vennetb (2008) studied the issue of bank interest margins in Central and Eastern Europe. Eicher and Leukert (2009) conducted an analysis of the endogenity and heterogeneity of the parameters used in analyzing the economic performance of institutions. Hakens and Schnabel (2010) investigated the essential elements of credit risk transfer and banking competition. Jiménez et al. (2013) investigated whether banking risk is influenced by banking competition. Ly (2015) addressed issues related to liquidity risk, regulation in the field, and bank performance.

\section{Research methodology and data. Results and discussions}

Analysis of the loan portfolio with a view to provisioning is a stage in the credit risk management that precedes the credit granting process and aims at providing resources to cover the losses that may occur in the loan portfolio. Determining the level of provisions for credit risk is determined by the banking regulations in force and the sensitivity of the loan portfolio. In this respect, the provisions of Regulation no. $1 / 2018$, for the classification of loans, for the provisioning of provisions, of the National Bank of Romania. This regulation implements the provisions of IFRS 9. In the data processed and presented, taking into account that banks have in their portfolio and long-term loans contracted several years ago, we also took into account the previous regulations. First, we classify the loans into five categories according to their specificity and for each category a provisioning level is set:

Table 1. The credit category and the provisioning rate

\begin{tabular}{|c|c|c|c|c|c|}
\hline Credit category & Standard & In observation & Substandard & Doubtful & Loss \\
\hline Provisioning coefficient & 0 & 0.005 & 0.2 & 0.5 & 1 \\
\hline
\end{tabular}

Clients 'classification is made taking into account the assessment of the clients' financial performance and their ability to honor the accumulated debt on maturity. 
Financial performance is evaluated by each bank and, in this context, credits will be included in one of the following categories:

- Category 1: Very good performance. which allow for debt to be matured while maintaining that performance;

- Category 2: good performance but fairly certain on average;

- Category 3: satisfactory financial performance, worsening trend;

- Category 4: low and cyclical financial performance;

- Category 5: losses and inability to repay.

In general terms, the debt can be regarded as good (repayments after maturity, with a maximum delay of 7 days); (delays up to 30 days) and inadequate (delays over 30 days.

Depending on these two criteria, the loans are classified according to the data in the following table:

Table 2. Classification of credits by performance level

\begin{tabular}{|l|l|l|l|}
\hline \multirow{4}{*}{ Subgroup } & \multicolumn{3}{|c|}{ Debt service } \\
\cline { 2 - 4 } & Good & Weak & Inadequate \\
\cline { 2 - 4 } & Standard & In observation & Substandard \\
\cline { 2 - 4 } & In observation & Substandard & Doubtful \\
\cline { 2 - 4 } & Substandard & Doubtful & Loss \\
\cline { 2 - 4 } & Doubtful & Loss & Loss \\
\cline { 2 - 4 } & Loss & Loss & Loss \\
\hline
\end{tabular}

According to the lending policy, mature and doubtful maturities can be considered differently.

Thus, the effective treatment of these loans involves either collecting funds from reduced claims or switching to losses, or renegotiating for the cancellation of the claim. Part of the interest rate charged by the bank on loans granted may be a way of indirectly financing risks. When determining the average interest rate negotiated with the client, the bank considers two strategies: pricing at a cost or charging according to the bank solvency rate.

Cost pricing of the bank interest rate is calculated based on the cost of credit resources used by the bank. If credit resources come from a bank, a weighted average cost of borrowed funds is used. When special resources are used then their cost should be corrected by a percentage share of general expenses. The ROI is calculated based on the Financial Revenues Rate (RRF) using the relationship:

$\mathrm{PR}=\mathrm{RRF} /(1-\mathrm{t}) * \mathrm{k} / \mathrm{p}$

Where:

$\mathrm{PR}=$ return on profit; RRF = Financial Return Rate; $\mathrm{t}=$ average (average) loan share;

$\mathrm{k}=$ capital; $\mathrm{p}=$ placements.

Charging on own-fund coverage determines that at these base rates a risk premium is added that expresses the static risk of default. appreciated by credit quality, based on internal data from earlier periods, in terms of comparability in terms of the economic cycle phase.

The warranty is the name used to designate any method, instrument or commitment that is ancillary to the loan agreement made available to or in favor of the bank by virtue of the contract concluded to provide the bank with a clear guarantee of the guaranteed rights, credit and cost, including interest, in the event of default by borrowers.

The guarantees are executed in the event of the debtor's insolvency to recover the uncovered debit.

The obligation in the credit agreement is the main obligation. The customer is obliged to repay the due installments and the related interest on the contracted terms. The additional guarantee gives rise to a second relationship. If the initial commitment was not fulfilled, the bank shall call for the guarantee to be executed. There are many types of collateral, with different features and uses, requiring specific documentation to allow banks to enjoy the rights that these guarantees give them.

Providing additional guarantees has. in principle, two alternatives, namely: he guarantees with material goods, immovable property, land or financial assets which he makes available to the bank in the form of a mortgage, pledge, bank deposit etc . these are called real collateral or call on a guarantor he/she 
will record the obligation to pay off the debt if the one for whom he/she guarantees (the debtor) fails to fulfill his obligation under the loan agreement. Thus, it issues and presents a bank guarantee letter.

In order to fulfill its purpose, the guarantor must meet certain requirements as follows: the existence of a patrimony independent of the contractual relationship, sufficiently large and demanded over time. to cover the guaranteed obligation; the guarantee is designed in such a way as to enable the bank to execute it without the debtor's opposition; the bank, as the beneficiary of the collateral, has a high degree of liquidity if it is to be executed if the client does not repay its debt.

The main types of collateral used and defined in a bank's internal lending rules may be set out below.

The mortgage serves to guarantee the debtor's obligations to his lender by means of a piece of immovable property in the patrimony, which is legally designated for that purpose. This guarantee is that. if at the maturity date the borrower does not reimburse the related rates and obligations, the bank may require the sale of the mortgaged property and from the amount obtained to cover its receivables. In practice, there are two major issues that need to be considered in the case of the mortgage. The first is how to evaluate. Even if a professional assessment is obtained, unexpected (force majeure) events can alter the real value of collateral. To avoid losses, the mortgaged property is secured to an insurance company and the insurance policy is endorsed by the creditor bank. The second difficulty lies in the time needed to sell the property, especially in a stagnant real estate market or in which there is a surplus of real estate and a low demand. The two aspects are covered by bank validation.

Pledge means the alienation of the good and consists in the debtor giving in favor of the lender another mobile asset that. if the debt is not paid on maturity, it will be sold and the debt of the debtor will be covered by the money obtained. The pledge may be with or without dispossession (in the latter case the goods remain in the debtor's possession). As a rule, any good may be used as collateral if it meets the following conditions: the pledged asset has a sufficient value in relation to the guaranteed claim and the value is constant or even increasing over time in the case of a good, it is insured to a company insurance or stored for retention at specialized institutions.

Bank deposit is the ideal guarantee, customers who provide a bank deposit as collateral, and will be collateral. The bank deposit is accessible at any time, it is in the form of a fixed amount. known to the bank, and when the deposit is made in a currency other than the one in which the loan was made, the bank must take into account the risks arising from exchange rate fluctuations of the two currencies in order to cover and exchange rate risk.

Before accepting a guarantee, regardless of the nature of the underlying obligation or the guarantee instrument used, the bank must consider three aspects, namely: the right to property, the performance of the guarantee contract and the amount of the guarantee.

In the case of real collateral, such as the mortgage, it is important to know if it is free from any other obligation. The performance of the guarantee contract is a generic term to designate all the activities and requirements imposed by the law and whose observance guarantees the bank the rights to the established guarantee. The appreciation of the guarantee depends on some aspects, such as: knowing the legal code for the use of collateral, both for compliance with specific laws and bank rules; the fulfillment of all legal formalities so that the bank, as the beneficiary, has assured the possibility of using the guarantee if the money has to be recovered; the priority documents of the guarantee must be designed to give the bank the right and the ability to execute the bank so that the borrower can oppose and any collateral involves certain costs, the bank has to assess them and determine who they bear.

Basically, banks calculate the coverage level provided by the guarantee, in relation to the value of the guaranteed obligation. The goods offered as collateral are finally valued by the bank's specialists. The level of coverage reflects the bank's experience of being able to collect as much as possible from the guarantee as a result of its execution.

Non-performing loans generate the highest risk management costs for the bank. The maximum cost level is reached in the case of overdue loans that can not be recovered and which are covered by the reserve fund or the risk fund. Covering leads to a corresponding decrease in the bank's assets and liabilities. Non-performing loans, as a rule, are retained in the portfolio and are not yet loss-making, with no chance of loss. For this reason, the expenses related to their management must include: the increase in administrative costs imposed by the separate and preferential administration of these credits as they may 
appear as an opportunity cost; the increase in legal costs in the case of appeal to the court and the deterioration of the bank's image vis-à-vis shareholders.

In addition to the provisions specific to each type of credit, there is also the option of providing credit risk reserves. The legislation provides for a tax deductible amount of the general credit risk reserve of up to $2 \%$ of the balance of credits granted. Reserves can cover losses on the loan portfolio in the event of inappropriate provisioning. This results from the relationship:

$\operatorname{Rgrc}=2 \% \times \mathrm{Cr}$

Where:

Rgrc $=$ the general credit risk reserve; $\mathrm{Cr}=$ balance of credits granted .

Assurances are made for goods that constitute a material guarantee of the credit granted or life and accident insurance for private holders of long-term credit agreements. The problem of the debtor's guarantees is very important. As a rule, the valuation of material guarantees is carried out by the bank's specialized department or by a specialized firm approved by the bank. With all these precautionary measures, situations arise where the occurrence and manifestation of risks exceed the expected damage level. Risk Considerations are based on the establishment of own bank funds to cover any losses on the loan portfolio. Establishing funds to cover potential losses is to reduce the gross profit of the budget exercise, which calls into question the level of profitability of the bank. Of course, this problem occurs when the losses occur and the fund constituted is used.

When emerging non-performing loans compete. in general, internal factors, which are related to the specificity and the manner of operation of the bank and external - environment and conjuncture.

These factors often act together and, of course, independent of the will of the parties.

As factors of non-performing credit we can remember: the phases of the economic cycle; economic, political, social, national or international conjuncture; (Basel agreements) or natural disasters. By detailing the occurrence and the influence of the factors that lead to the passage of credits into the category of nonperforming loans, we find that the "economic cycle phases" are the most difficult to anticipate, especially when the loan portfolio contains many long-term credits. Thus, in 2007-2008, when the effects of the global economic and financial crisis appeared on the financial-banking market, many credit was hit by the "credit risk" effect, many of which remained insufficiently covered by solid guarantees. The cumulative effect with other risks has resulted in the passage of many credits into non-performing ones.

The economic, political or social, national or international conjuncture produces negative effects on banks' lending activity. For example, lending in foreign currency, usually in Swiss francs or the euro, has produced disastrous effects on customers (borrowers) and even on banks because of the change in the exchange rate of the domestic currency against the currencies underlying the contracting loans. So the conjuncture in the domestic and international financial market has changed and the effects have emerged. It was found that government intervention was attempted by strengthening a exchange rate that did not have the desired outcome. There are still enough credits in the first-house operation, whose cost has increased so that the "mortgage" category, when executed, no longer covers the effect of credit risk, not to mention the losses suffered by creditors. We will also make no mention of the causes of force majeure, which are easy to analyze as an effect on credit.

These factors act on clients and therefore their identification and evaluation are done by bank specialists. In the internal factors category we mention: performing an erroneous credit analysis based on incomplete or inappropriate documentation, misinterpretation of financial results and customer creditworthiness, use of incomplete analysis procedures, failure to take into account some risk factors; unfavorable changes in the economic factors after the credits have been granted, so that the borrower can not achieve what he has proposed; improper management or inappropriate management changes, organizational structure or organizational structure of the client, and failure to report in time the action signal on inappropriate performance of the client's activity. That is why, in the study, we have sought to highlight the sensitivity of the level of provisions (risk hedging funds) that are created together with the possibility that some factors may lead to net effects higher than the predicted risks. 


\section{Conclusions}

From the authors' submissions, there is a close link between the loan portfolio and the provisions. The bank management system should consider a concrete plan of measures to provide for those measures that need to be taken when the impact of credit risks arises. It is concluded that the avoidance of such a risk can be made depending on the size of the bank's loan portfolio, but it must be ensured by consistent guarantees or/and not least by provisioning, ie funds to be used in covering financial effects when bad loans occur. Another conclusion is that, in the context of the lack of a correlation between the loan portfolio and the established provisions, there may be a series of risks leading to the diminishing of the bank's results and, last but not least, the difficulty of insolvency or even bankruptcy. Lastly, a necessary conclusion is that banks must strictly abide by the rules of the central bank (the National Bank of Romania), but also the provisions of the Basel agreements stipulating and realizing, impose a strict concordance between the size of own funds, attracted sources and credits granted in such a way as to avoid as much as possible the issue of occurrence of risks.

\section{References}

1. Aebi, V., Sabato, G. and Schmid, M. (2012). Risk management, corporate governance, and bank performance in the financial crisis. Journal of Banking and Finance, 36, 3213-3226

2. Agarwal, S., Chomsisengphet, S., Mahoney, N. and Stroebel, J. (2018). Do Banks Pass through Credit Expansions to Consumers Who want to Borrow?. The Quarterly Journal of Economics, 133 (1), 129-190

3. Agoraki, M.E., Delis, M.D. and Pasiouras, F. (2011). Regulations, competition and bank risk-taking in transition countries. Journal of Financial Stability, 7, 38-48

4. Anghel, M.G., Niţă, G. et al. (2016). Analysis Model of credit Risk. Romanian Statistical Review Supplement, 5, 65-72

5. Anghel, M.G. (2015). Analiză financiar-monetară, Editura Economică, Bucureşti

6. Anghelache, C., Anghel, M.G. and Bodo, G. (2017a). Theoretical aspects of the role of information in the process of decisions/risks modeling. Romanian Statistical Review, Supplement, 6, 102-111

7. Anghelache, C., Marinescu, I.A. and Mirea, M. (2017b). Models of Insolvency Risk Analysis in Financial and Banking Institutions. Romanian Statistical Review, Supplement, 11, 72-78

8. Anghelache, C., Anghelache, G.V., Anghel, M.G. and Niţă, G. (2016). General Notions on banking Risks. Romanian Statistical Review Supplement, 5, 13-18

9. Anghelache, C. and Anghel, M.G., Modelare economică. Concepte, teorie şi studii de caz, Editura Economică, Bucureşti, 2014

10. Anghelache, C. (2010). Metode şi modele de măsurare a riscurilor şi performanţelor financiar-bancare, Ediţia a II- $a$, Editura Artifex, Bucureşti

11. Anghelache, C., Dincă, I., Asmarandei, A. and Sfetcu, M. (2009). Principalele măsuri de prevenire a riscurilor bancare. Romanian Statistical Review, Supplement, 6, 123-126

12. Awdeh, A. et al. (2011). The Effect of Capital Requirements on Banking Risk. International Research Journal of Finance and Economics, 66, 133-146

13.Bushman, R. and Williams, C. (2012). Accounting discretion, loan loss provisioning, and discipline of Banks' risk-taking. Journal of Accounting and Economics, 54 (1), 1-18

14.Chen, G. and Wu, Y. (2014). Bank Ownership and Credit Growth in Emerging Markets During and After the 2008-2009 Financial Crisis A Cross-Regional Comparison. International Monetary Fund in its series IMF Working Papers

15. Claeysa, S. and Vander Vennetb, R. (2008). Determinants of bank interest margins in Central and Eastern Europe: A comparison with the West. Economic Systems, 32, Issue (2), 197-216

16. Eicher, T. and Leukert, A. (2009). Institutions and Economic Performance: Endogeneity and Parameter Heterogeneity. Journal of Money, Credit and Banking, Blackwell Publishing, 41 (1), 197-219

17. Hakens, H. and Schnabel, I. (2010). Credit Risk Transfer and Bank Competition. Journal of Financial Intermediation, 19 (3), 308-332

18.Jiménez, G., Lopez, J. and Saurina, J. (2013). How does competition affect bank risk-taking?. Journal of Financial Stability, 9 (2), 185-195 
19.Ly, K.C. (2015). Liquidity Risk, Regulation and Bank Performance: Evidence from European Banks. Global Economy and Finance Journal, 8 (1), $11-33$

20. ${ }^{* * *}$ Regulamentul nr. 1 / 2018 al Băncii Naționale a României. 